Nemyrovskyi, Y., Posvyatenko, E., \& Sardak, S. (2020). Technical-Economic Aspects of the Use of Technological Process of Deforming Broaching. Advances in Design, Simulation and Manufacturing II. DSMIE 2019. Lecture Notes in Mechanical Engineering. Springer, Cham, 238-247. DOI: 10.1007/978-3-030-22365-6_24

\title{
Technical-economic aspects of the use of technological process of deforming broaching
}

\author{
Ya. B. Nemyrovskyi ${ }^{1}$, E. K. Posvyatenko ${ }^{2}$, S. E. Sardak ${ }^{3}$ \\ ${ }^{1}$ Central Ukrainian National Technical University, Kropyvnytskyi, Ukraine \\ provotorova1951@gmail.com \\ ${ }^{2}$ National Transport University, Kiev, Ukraine \\ natali1963@ukr.net \\ ${ }^{3}$ Oles Honchar Dnipro National University, Dnipro, Ukraine \\ dnus@ukr.net
}

\begin{abstract}
The article gives a definition of the technical and economic potential of the application of the deforming broaching process. Research of the consequences of introducing deforming broaching into technological processes at manufacturing enterprises is carried out on the basis of application of system resource and matrix approach. On the basis of the performed researches, a methodological basis for the economic evaluation of the results of applying deforming broaching on the production has been developed. The article has improved the well-known scientific and methodological foundations for the determination of technical and economic results of the application of deforming broaching due to the complex identification of production-organizational decisions - in technical and forms of evaluation in economic spheres. The developed approach gives an opportunity to more accurately assess the economic effect of introducing deforming broaching on the mining, metallurgical and machine building industries. It can be used to assess the economic effect of introducing other process parts processing.
\end{abstract}

Keywords: deforming broaching, economic effect, efficiency, resources, saving, products, restoration, machining.

\section{https://link.springer.com/chapter/10.1007/978-3-030-22365-6_24}

\section{Conclusions}

In the course of the study, the authors identified technical and economic potential of the use of deforming broaching as a set of existing and potential capabilities of the rational use of human, natural, technological, power, raw material and material, technical, financial, intangible, information and time resources.

The authors presented the content and features of application of the technology of deforming broaching in production. The examples of using the technology of deforming broaching from the 70 s of the XX century till the end of the 20 s of the XXI century at the production in 
different types of economic systems (both in the administrative ordering, and in transformation and market systems) were analyzed.

The general technical aspects were highlighted, the advantages were determined and the main directions of improvement of the technology of deforming broaching that ensure the existence of economic effect were developed.

Scientific and methodological basis of economic evaluation of the results of application and optimization of deforming broaching due to the identification and formalization of resources, types of records, methods and principles of evaluation were developed.

The prospects of subsequent research in this area involve identification of the factors of increasing the economic effect from the application of the technology of deforming broaching at a modern production enterprise.

\section{References}

1. Krivosheja, V. V.: Effect of the deformation angle on the extension of cylindrical holes. Monograph. LAP LAMBERT Academic Publishing, Saarbrucken (2015).

2. Nemyrovskyi, Ya. B.: Accuracy control for products manufactured by deforming broaching. Metallurgical and Mining Industry No.7, 6-18 (2017).

3. Posvyatenko, E. K., Nemyrovskyi, Ya. B., Cherniavskyi, O. V., Yeromin, P. M.: Mechanics of combined broaching of graphite-containing pig-iron. Monograph. Central Ukrainian National Technical University, Kropyvnytskyi (2017).

4. Stukalo, N., Krasnikova, N., Steblianko, I. et al.: «Green» economy: from global concept to reality of local development. Publisher, Serednyak (2018).

5. Grushko, A. V.: Determination of work hardening during deforming broaching of thickwalled pipes. Scientific Herald of the Donbass State Engineering Academy 2(14E), 18-26 (2014).

6. Rostotsky, I. Yu.: Improving the process of deforming broaching holes in parts of titanium alloys. Unpublished PhD dissertation. V. Bakul Institute for Superhard Materials, Kyiv (2016).

7. Shepelenko, I. V., Warouma, A., Sherkun, V. V.: Restoration of bronze bushes by the method of surface plastic deformation. International Journal of Engineering \& Technology 5(1), 29-32 (2016).

8. Zanger, F., Boev, N., Schulze, V.: Surface quality after broaching with variable cutting thickness. Procedia CIRP 13, 114-119 (2014).

9. Bobrovskiy, N. M., Melnikov, P. A., Bobrovskiy, I. N., Levitskih, O. O.: Development and commercial implementation of high performance manufacturing and environmentally appropriate technology of surface plastic deformation of cars parts. Vector of sciences. Togliatti State University 2(32-2), 32-37 (2015).

10. Hosseini, A., Kishawy, H. A., Moetakef-Imani, B.: Effects of Broaching Operations on the Integrity of Machined Surface. Procedia CIRP 45, 163-166 (2016).

11. Velychko, O.: Fundamental basis and connection of modern entrepreneurial logistics and SCM. Review of European Studies Vol. 6 No. 4, 135-146 (2014).

12. Smerichevskyi, S., Kryvoviaziuk, I., Raicheva, L. et al.: Research on the development of the machine-building industry of Ukraine: state and prospects. Publisher, Baltija Publishing (2017). 